\title{
The potential of integrated GPR survey and aerial photographic analysis of historic urban areas: A case study and digital reconstruction of a Late Roman villa in Durrës (Albania)
}

\author{
Daniele Malfitana $^{\mathrm{a}}$, Giovanni Leucci ${ }^{\mathrm{a}, *}$, Giovanni Fragalà ${ }^{\mathrm{a}}$, Nicola Masini ${ }^{\mathrm{a}}$, Giuseppe Scardozzi ${ }^{\mathrm{a}}$, \\ Giuseppe Cacciaguerra ${ }^{a}$, Cettina Santagati ${ }^{\mathrm{b}}$, Eduard Shehi ${ }^{\mathrm{c}}$ \\ a Istituto per i Beni Archeologici e Monumentali, CNR, Italy \\ ${ }^{\mathrm{b}}$ Department of Architecture, University of Catania, Italy \\ c Albanian Institute of Archaeology, Department of Antiquities, Durrës, Albania
}

\section{A R T I C L E I N F O}

\section{Article history:}

Received 1 November 2014

Received in revised form 19 September 2015

Accepted 23 September 2015

Available online $\mathrm{xxxx}$

\section{Keywords:}

Urban archaeology

Roman archaeology

Image processing

GPR survey

Durrës (Albania)

3D modelling

Virtual reconstruction

\begin{abstract}
A B S T R A C T
This paper focuses on the results of a joint geoarchaeological research project of urban historical remains in the ancient Roman city of Durrës, Albania. The project began with a desk-based analysis of all the historical and archival evidence including aerial photos from the $1920 \mathrm{~s}-40 \mathrm{~s}$, a period before major urbanization of the area and prior to the capture of satellite imagery in the 1960s. These aerial photographs were re-processed and then combined with ground-penetrating radar (GPR) imagery and used to locate a Late Roman villa in the city. The integrated results produced a visual idea of what the villa looked like, when analysed in conjunction with the known archaeological and historical literature. During analysis, different levels of data reliability and resolution have been identified, which inform methodological choices when undertaking reconstructions of the villa. These methodological issues have generic resonance in the reconstruction of urban landscapes.
\end{abstract}

(c) 2015 Elsevier Ltd. All rights reserved.

\section{Introduction}

Shallow geophysical techniques including geolectrical resistivity tomography, self potential, electromagnetic, and magnetic methods have been used to investigate the archaeological remains of a number of sites such as Roman towns and other features in the ancient Mediterranean world, (Ciminale and Ricchetti, 1999; Mulvin, 2002). However, some factors such as variations in the complexity of the sites themselves and ground surfaces limit the efficacy of these methods and the stratigraphy of an archaeological site may be too complex to be reconstructed using existing techniques (McCann, 1995; Leucci, 2002; Conyers, 2012, 2013). This is especially true for areas where human settlements have existed in the same location for centuries, which is common in urban areas or stratified settlements on what become artificial hills.

In urban archaeology there are other restrictions such as the presence of modern buildings, water pipes, buried and above ground telephone cables to name but a few. This is why, apart from specific investigations over limited areas that are conducted by civil engineers using techniques such as tomography to identify pillars and other

\footnotetext{
* Corresponding author.
}

foundation, it is often difficult to apply archaeological geophysics in urban areas (Conyers, 2012).

Nevertheless, the need for geophysical mapping for archaeology in such areas is growing because of the rapid development of new infrastructure such as parking facilities, roads, and buildings, but also because of the greater recognition of the importance of cultural heritage.

Urban settings are one of the most challenging areas for near-surface geophysical mapping of archaeology and ground-penetrating radar (GPR) is one of the most appropriate methods for such environments since it transmits energy into the ground with only minor interference from surrounding cultural materials (Conyers, 2013). Archaeological prospecting using GPR has been used widely and successfully applied in a number of ways including the: i) search for graves, burial sites, or human remains; ii) detection of buried foundations, walls, floors and other housing structures, and sometimes, man-made objects and; iii) discovery of ancient villages buried by volcanic eruptions (Malagodi et al., 1996; Conyers and Goodman, 1997; Leucci, 2002; Leucci and Negri, 2006; Leucci, 2006; Conyers, 2012, 2013; Leucci et al., 2014). When focused three-dimensional data captured by GPR are combined with the results of aerial and satellite remote sensing analysis, this provides a robust method for locating areas that are likely to contain archaeological sites and is especially powerful in urban contexts The capture and integration of these multi-method datasets, processed 
using ever more sophisticated software, is a relatively new advance in urban archaeology, which has significant potential (Leucci, 2006).

The site that is the focus of this paper was identified through aerial photograph interpretation of historical vertical prints taken in 1928 by the SARA company of Rome (Archive of Military Geographical Institute, Flourence, 1928). Unfortunately, given their age, these photos were not georeferenced and so precise locations in the field can only be estimated. However, their analysis using improved image enhancement methods has allowed general identification of (old) excavations at the site of the Roman villa within modern Durrës. Here we show how the quality and quantity of the information collected through an integrated programme using multiple data sources has opened up a new perspective for archaeological research at this urban site, which could be applied to other areas. As well as analysis of the aerial photographs and GPR, field-walking surveys were also undertaken as part of the project.

\section{The geoarchaeological research project}

The objective of the multidisciplinary geoarchaeological research project was to understand the topography of the ancient city of Dyrrachium (Durrës), on the coast of Albania (Fig. 1). It was first a Greek colony, which was founded under the name of Epidamnos and then it became, under the Roman rule, Dyrrachium, a prosperous city from which the Via Egnatia started to reach Byzantium. Because of the recent history of Albania, this important site is still little known beyond the region.

The rapid urbanization of the modern city of Durrës has developed immediately above the antique city. Therefore, in order to investigate the ancient town-plan of Epidamnos/Dyrrachium and in particular, the different phases of its development from the Greek to the Byzantine period, it was necessary to develop a multi-tool approach. Initially, the project developed a Geographic Information System (GIS) to capture, store and manage all archaeological datasets as well as geological, geophysical and hydrological information that also inform an understanding of the site.

Ultimately, the GIS and all its datasets will be used to develop a zoned archaeological risk map that will inform managers of the importance of archaeological remains across the city and where building activity should be strictly regulated or allowed. The first campaigns of this project and GPR investigations, including a general survey of the urban area containing the "suburbium" (i.e. the space between the town and its hinterland) and GPR investigations, were undertaken in the spring of 2010.

A primary aim of the Durrës geoarchaeological project is to investigate the settlement history of the town and how it was influenced by the complex regional environment in a wider Mediterranean perspective. It is hoped that the combined integration of evidence from geophysical, surveys, excavations, historical archives and aerial historical photographs will provide a more complete understanding of the ancient town and its history than would be possible from excavation alone.

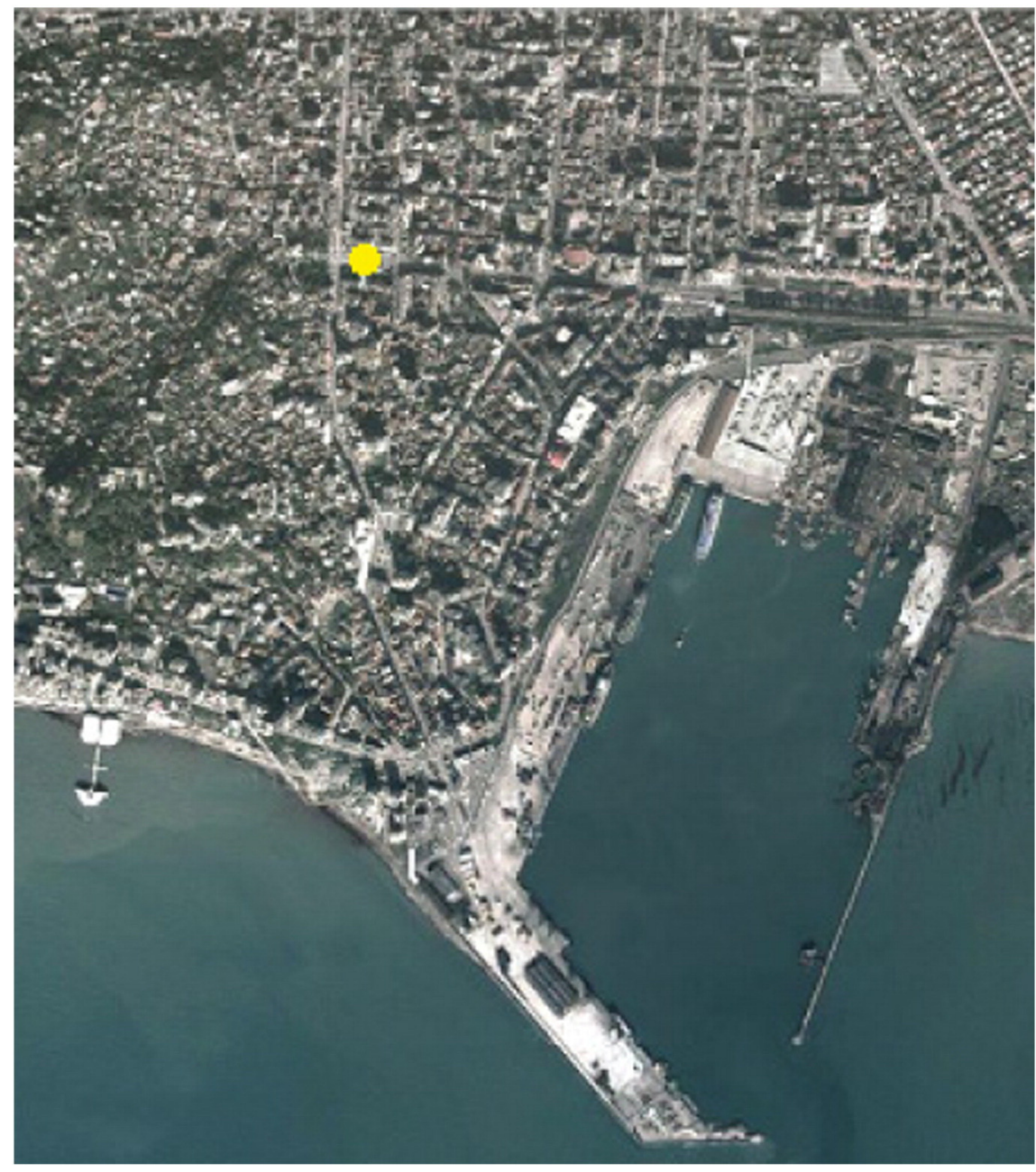

Fig. 1. View of Durrës (Albania) with the position of the Late Roman villa highlighted. 


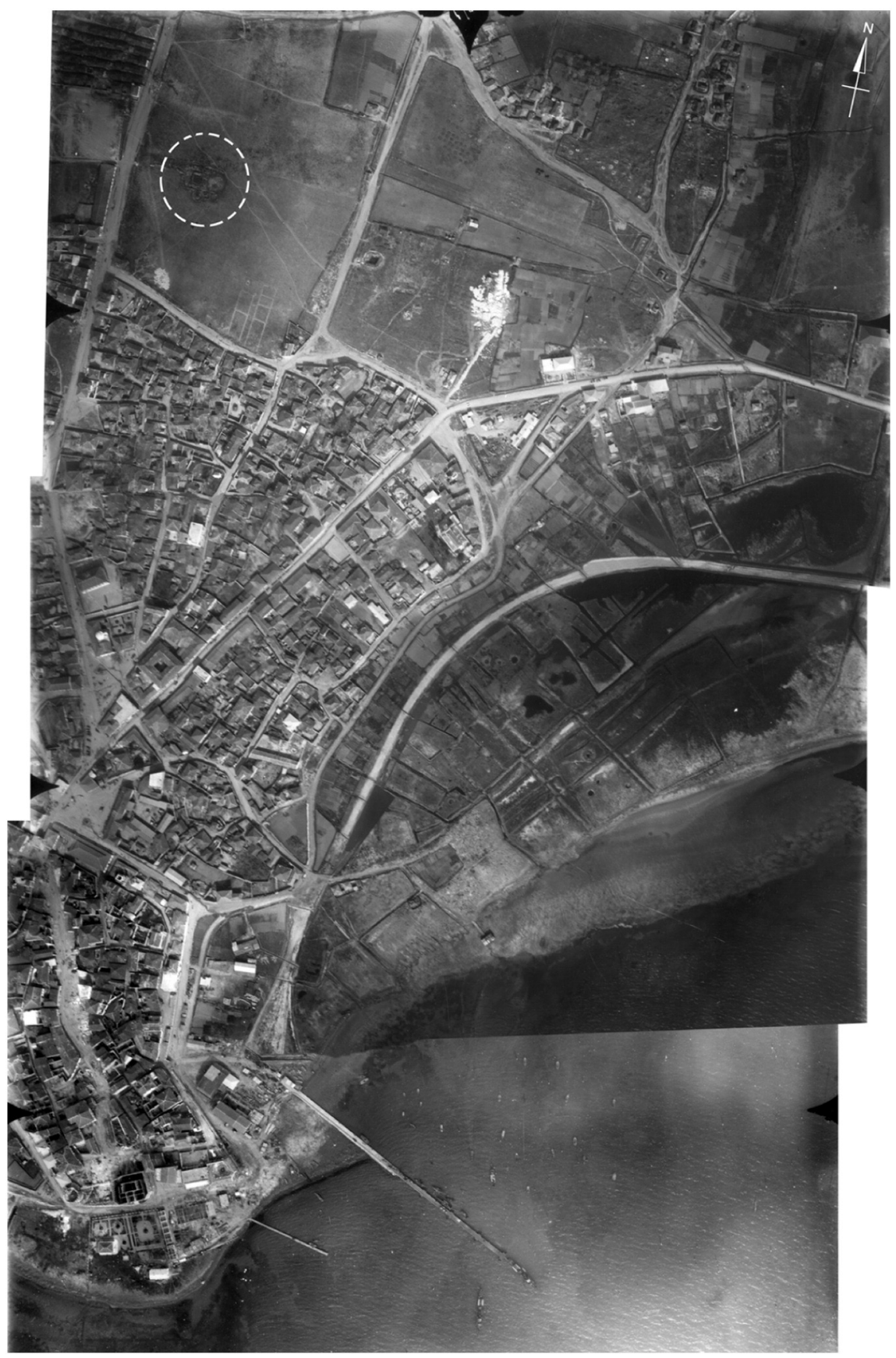

Fig. 2. Mosaic of three SARA aerial photos taken in 1928: the old centre of Durrës and the location of the excavated Late Roman villa in the northern periphery are visible.

\section{Historical setting}

The ancient city of Epidamne - Dyrrachion (Fig. 1) is situated on a peninsula facing the Adriatic Sea, surrounded by a lagoon. The oldest finds of the city belong to the 9th-8th Century. BC Colons coming from Corinth and Corcyra founded a Greek colony of Epidamnos (Thuc. I, 24) around 627 BC, which later became Dyrrachium under Roman rule from the end of the IIIrd Century BC. (Zeqo, 1986). The construction of the Via Egnatia c. 146 BC, which starts in Dyrrachium and heads to Byzantium, becomes an important factor in the commercial and cultural development of the city, which became a key stopover, as a centre of transit between Italy, the Balkans and beyond.

After the reforms of Diocletian, Dyrrachium became the capital city of the province of Epirus Nova, then, in the IXth Century AD, it became the capital city of the theme of Dyrrachium, a military and administrative division of the Byzantine Empire.

\section{Geological setting}

The region of Durrës sits in the Ionian Tectonic Zone, which is characterized by thick sedimentary deposits of lower Triassic age. The central-western parts of the Ionian Zone consists of the Pre-Adriatic tectonic depression, which includes the Durrës area. This depression is characterized by low hills, which are remnants of the eroded portions of anticlines and synclines, filled with Neogene sediments consisting of clay, marls, conglomerate and sandstone. In hydrogeological terms, the area of investigation has scarce water resources and has no perennial rivers. The lowlands in the Greek period was marsh that saw 


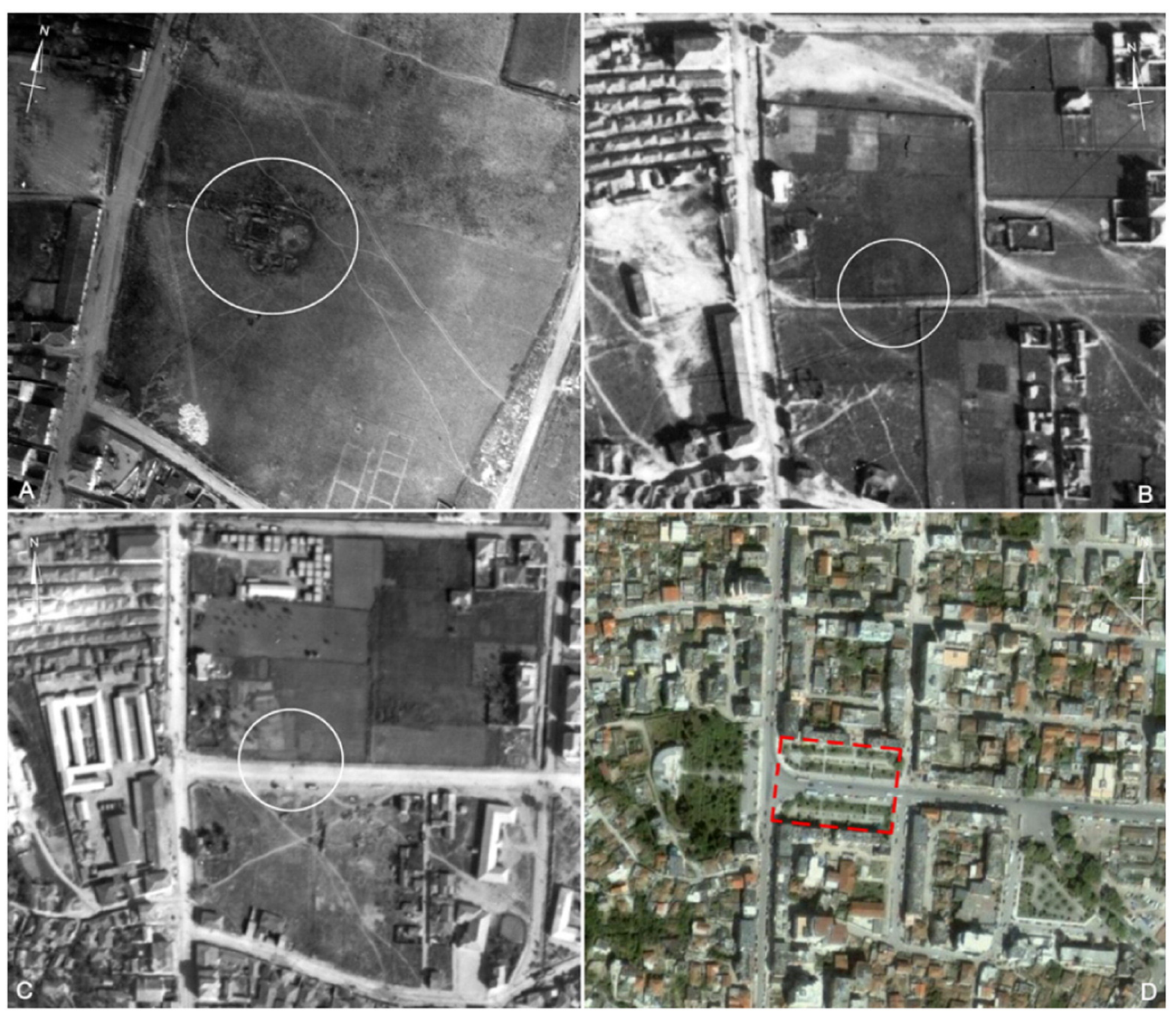

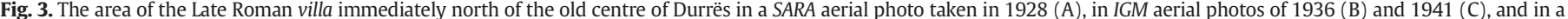
QuickBird-2 satellite image (D) of 2007 (from Google Earth) where the investigated area is highlighted.

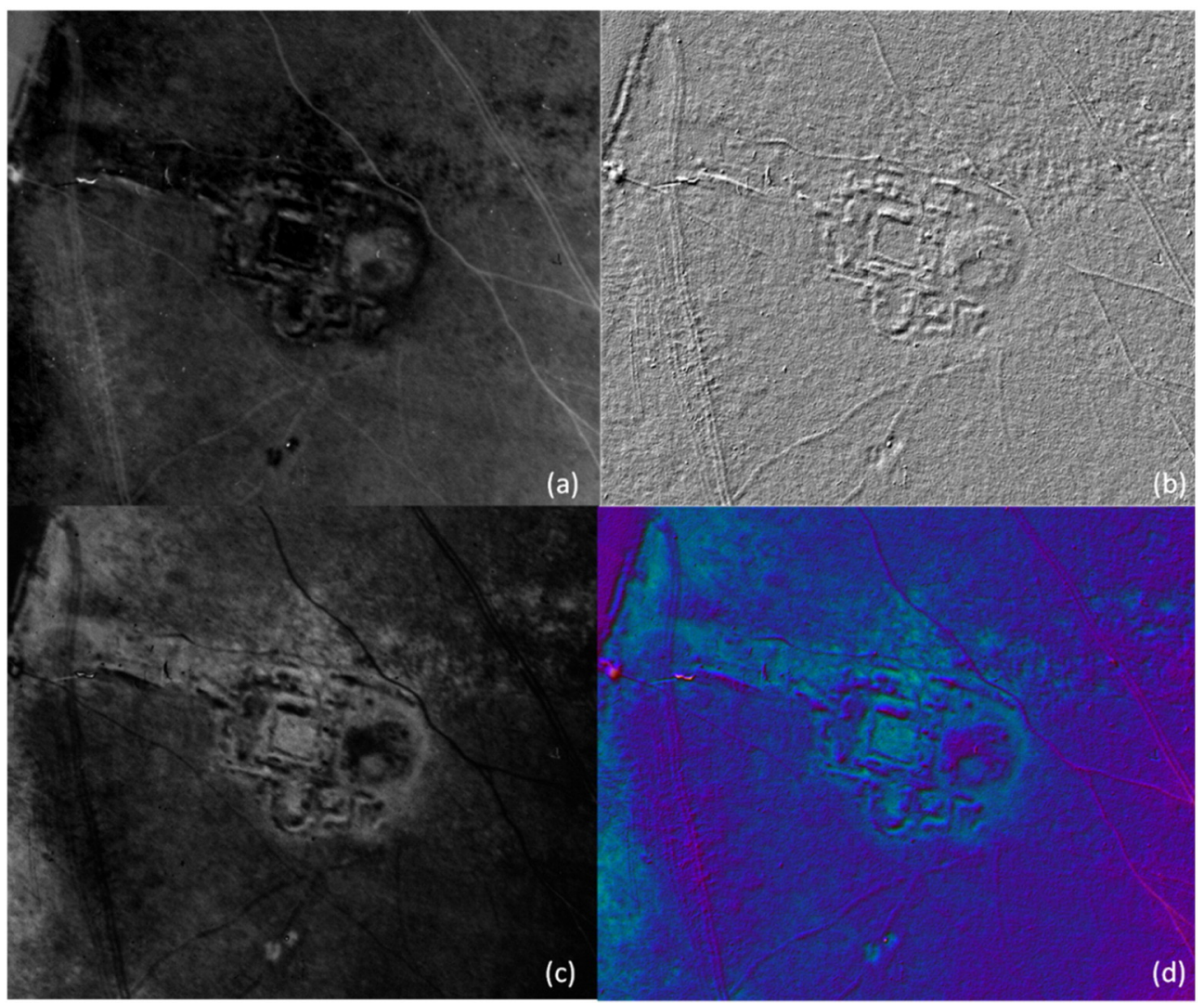

Fig. 4. (a) Non processed image; (b) result of convolution directional filter; (c) result of Moran index; (d) RGB composition of images (a), (b) and (c), respectively. 
temporary transgressions of the Adriatic Sea. After the construction (in the 1960s) of the road from Porto Romano to Bishti e Palles, the Durrës marsh was cut off from marine influence. Nowadays the marsh is frequently flooded during heavy rainstorms and it is characterized by presence of often stagnant waters.

The current lowlands were reclaimed in the 1980's when an artificial drainage channel and secondary feeder network were constructed to divert the seasonal rain water (and waste water) from Durrës to the sea. Dokle (2008) provides a comprehensive account of geological and hydrogeological knowledge of the region.

The Quaternary age sediments consist mainly of fine grained clays, clayey loams, sands and organic matter. Their maximum thickness in the centre of the area is about $50 \mathrm{~m}$. The soil for the major part of the area is rather saline, which creates difficulties for the electromagnetic energy sources used during GPR survey.

\section{Old aerial photos: A tool for the study and reconstruction of ancient topography}

A rich aerial photographic dataset is available from around 1910 until 1940 for the area of Durrës. Some of them were taken by the Italian Air Force, both Navy and Army, but they are rarely used in archaeological research investigating the ancient topography of Durrës. They include vertical and oblique photos taken in 1918 by Servizio Fotografico di Aviazione of Regia Marina and in 1936, 1937 and 1941 by Istituto Geografico Militare (IGM). In the IGM Archive in Florence, there are also some vertical aerial photos taken in 1928 by a private company from Rome named SARA (Società Anonima Rilevamenti Aerofotogrammetrici); these photos were used for the cartography of Durrës produced by the IGM itself. SARA was founded in 1921 by brothers Amedeo and Umberto Nistri and was the first company in Italy organized industrially to perform aerial surveys (Piccarreta and Ceraudo, 2000: 50-51; Boemi, 2003: 31, 41-42). During the 1920s and 1930s SARA was awarded numerous commissions in Italy and abroad for topographic and cadastral mapping. SARA used instruments designed by Umberto Nistri, which were produced by the company Ottico Meccanica Italiana (OMI), which was founded in Rome by Umberto Nistri in 1926 (Collier, 2002: 166). The Istituto Geografico Militare in Florence was founded in 1865 and is the Cartographic Agency of the Italian Army; during the 1930s and 1940s it used instruments designed by Ermenegildo Santoni, the other father of Italian photogrammetry, and produced by the Officine Galileo company in Florence. Nistri's early instruments used direct optical projection, while Santoni's instruments used mechanical projection. So, the SARA and IGM vertical aerial photos of Durrës, with their technical difference, represent an interesting page of the history of the Italian photogrammetry.

The images of 1918 (partially published in Rovigatti, 2010: 25) show the old city centre before the earthquake of 1926, with the Ottoman road network and fortifications still well preserved. The photos taken by SARA in 1928 (Fig. 2) also document the old city centre, which is superimposed on a part of the Roman town of Dyrrachium. In particular, they show the urban layout and damage caused by the earthquake of 1926 and immediately before subsequent development of the city, realized in the late 1920s and at the beginning of 1930s, visible in the IGM photos of the years 1936, 1937 and 1941. Moreover, the SARA photos document the lagoon to the north-east of the city and the ancient coastline, before the changes and enlargement of the harbour area made between 1928 and 1932.

The IGM photos taken in 1936 (both vertical and oblique, wrongly published as taken in 1928 in Rovigatti, 2010: 14 and 25; Santoro, 2010: fig. 1; Santoro and Sassi, 2010: fig. 1; Santoro, 2012: 94-95, fig. 3), 1937 and 1941 show Durrës after the enlargement of the harbour area and the construction of new roads and buildings following rationalization of city planning in the 1930s. They record the character of the city, prior to the urban expansion that followed the Second World War and more recent decades. So, for example, they allow the Roman city walls and the Byzantine fortifications that enlarge the town in a northerly direction to be reconstructed; it is also possible to see the survival traces of the amphitheatre, still unexcavated. These images even show the extent of the lagoon, north-east of the city and some stretches of coastline, that isolated the peninsula of Durrës, but which was reclaimed in 1962 (see also Santoro and Sassi, 2010: 37).

Therefore, the aerial photographic archive constitutes a very important record for the reconstruction of the ancient topography of the area of Epidamnos-Dyrrachium-Dyrrachion. However, in addition to providing an overview, they also allow detailed investigations of a few sectors of the city still not-urbanized, such as the area of the Late Roman villa partially excavated in 1920s, and immediately north of the old city centre of Durrës; today, it is buried under a modern road, gardens and buildings. In particular, a SARA photo taken in 1928 enables the location of the villa to be identified and contextualization of the structures in relation to the urban historic landscape (Fig. 2). It also allows a partial reconstruction of its plan; in fact, in 1928 the excavated structures of the villa were clearly visible in its layout (Fig. 3, A), while in 1936 it was already covered, though some traces are perceivable (Fig. 3, B). In the 1937 and 1941 photos (Fig. 3, C), the area was transformed and a road was built; these photos document the progressive urbanization of this sector of the Durrës periphery. The 1928 photo show a quadrangular peristyle with rectangular rooms around; on the southern side there was also a hall with an apse (se also Santoro and Monti, 2004: 530; Santoro and Sassi, 2010: 44-45, fig. 10). In the 1936 photo the excavated area was covered and crossed by a road, which still exists today; only traces of the re-buried peristyle and apsidal hall were visible.

\section{Historic photo enhancement}

In order to enrich the information provided by the 1928 photographic record, a series of spatial filtering and geo-statistic methods were applied (Fig. 4) (Lasaponara and Masini, 2012). The spatial filtering was employed to maximize the ratio signal-noise ratio and to improve the edge features of the surface remains of the Late Roman villa Anselin, 1995. Convolution

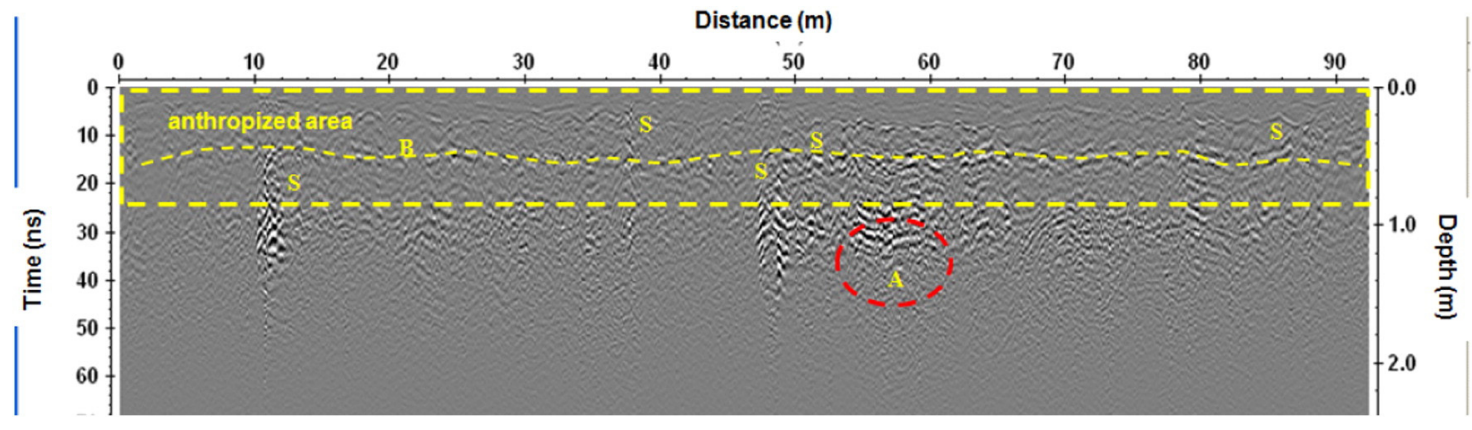

Fig. 5. GPR survey: processed radar section. 

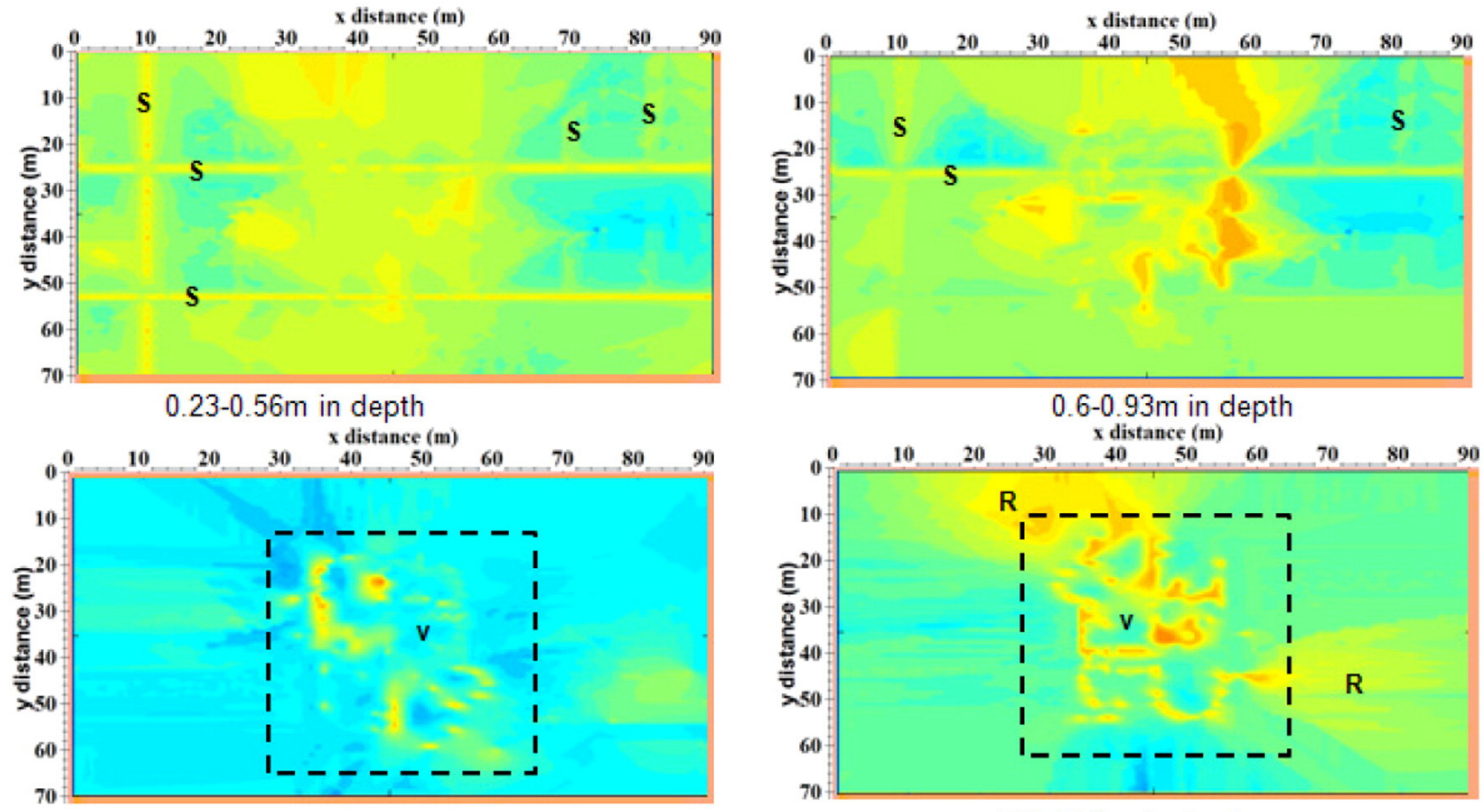

$1.16-1.49 \mathrm{~m}$ in depth

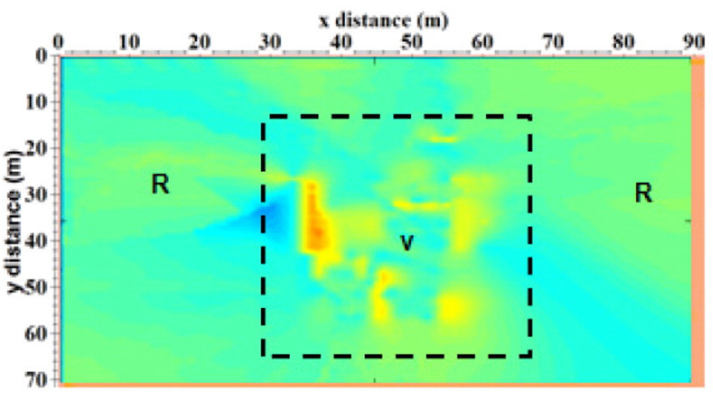

$1.69-2.02 \mathrm{~m}$ in depth

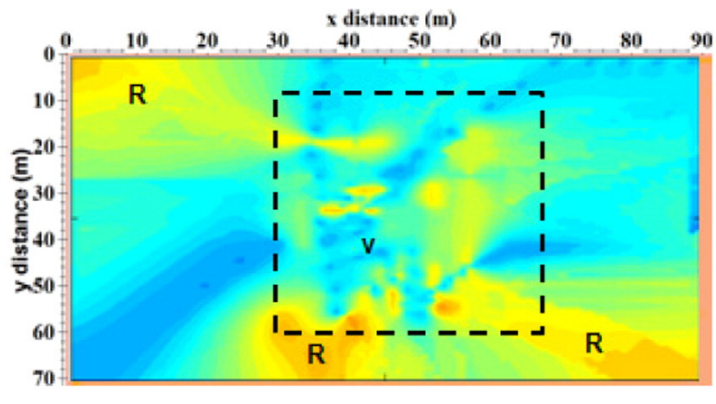

$1.92-2.25 \mathrm{~m}$ in depth

Fig. 6. Depth slices: S subsurface pipes; R bedrock; V Roman villa.

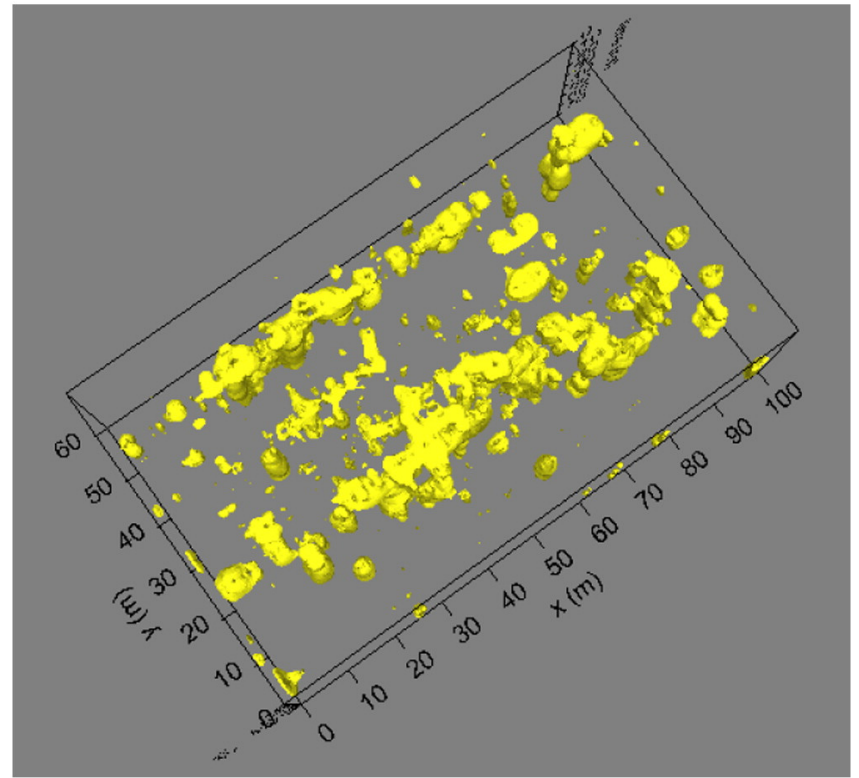

Fig. 7. 3D iso-amplitude surfaces using the threshold value of $30 \%$. filters, including High Pass, Laplacian, directional, Gaussian High Pass, Sobel and Robert filters were experimented with. The best results in terms of sharpening of the image and enhancement of the edges were obtained by directional filter angle, which is a first derivative filter that selectively enhances image features having specific direction components (gradients). The filter has been applied by adopting a $3 \times 3$ kernel and an angle equal to $45^{\circ}$ (Lasaponara and Masini, 2012).

A further methodological approach, based on spatial autocorrelation statistics, was also applied. This method is commonly employed in archaeological applications (Ciminale et al., 2009) to measure the extent to which the occurrence of one object/feature is influenced by similar objects/features in adjacent areas.

Two effects cause the presence of autocorrelation in a spatial distribution: 1) first order effects, which measure how the expected value varies in space, 2) second order effects, which focus on local interactions between events and are measured by covariance variations. Using this combination of techniques, a distribution can be: i) clustered, ii) uniform or iii) random, for which the autocorrelation will result in positive, negative and null respectively. As a whole, the output is a new image which contains a value of autocorrelation which could be done by computing global and local indicators.

Global indicators of autocorrelation measure, with one summarizing value, if and how much the dataset is autocorrelated. Local indicators of autocorrelation provide an understanding of where clustered pixels are, by measuring the number of homogeneous features inside the fixed 

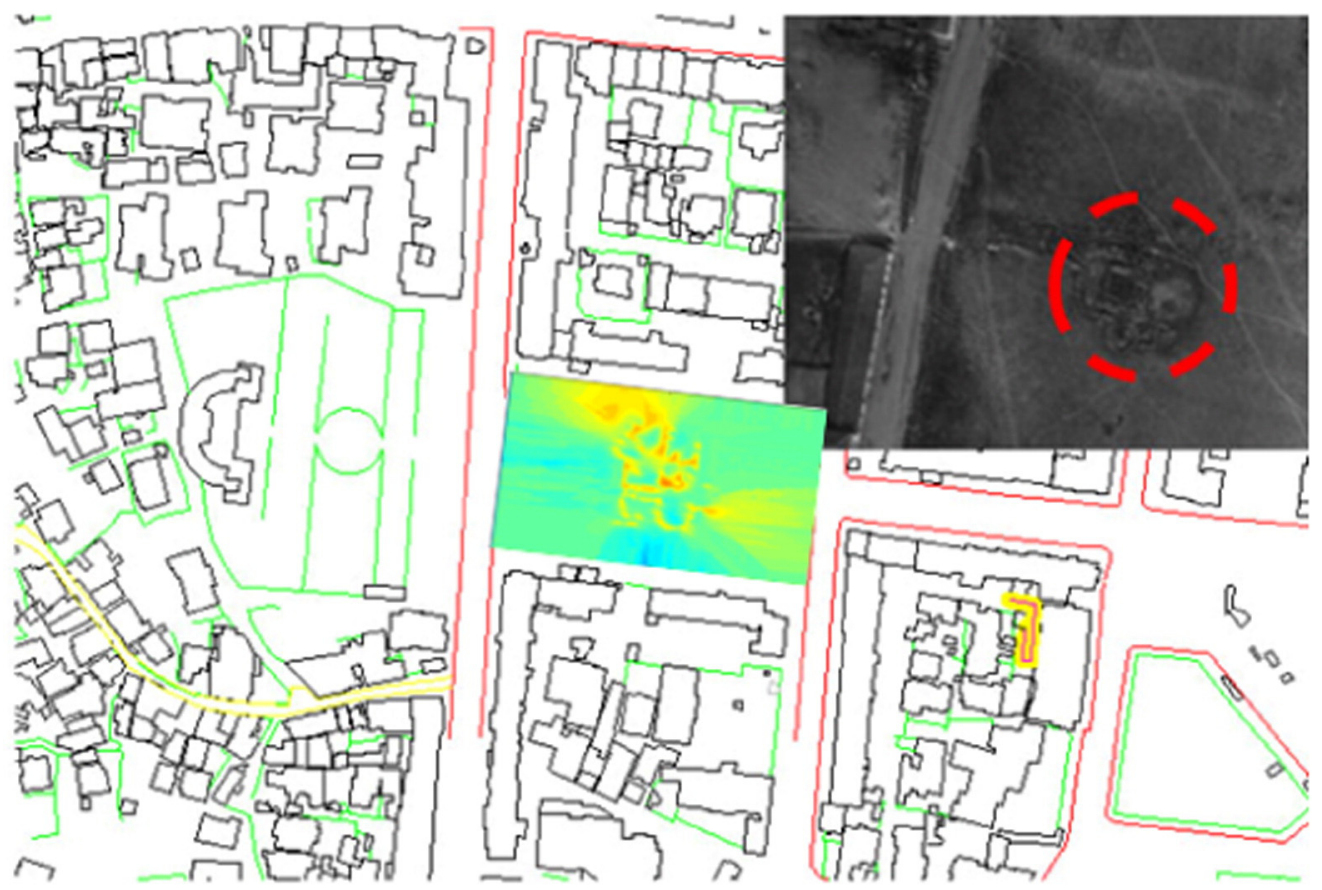

Fig. 8. GPR survey: depth slice at 1.39-1.72 m overlapped on the current map of Durrës and compared with the aerial photo taken in 1928 .

neighbourhood. In this study we used two indicators: the Local Moran's "I" and the Local Geary's "C" (Fig. 4).

These indicators show a different concept of spatial association:

1. in the Local Moran's I, a high value of the index means a positive correlation, both for high values and low values of intensity;

2. with the Local Geary's "C" it is possible to detect areas of dissimilarity between events.

In Fig. 4 the non-processed image (4a) is compared to the results of convolution directional filter (4b) and Moran index (4c). The convolution filter emphasizes the edges of archaeological features, making it easier to interpret some of the shapes, including circular ones. The Moran index acts by reducing the noise of the aerial photograph, thus improving the visibility of the archaeological features.

RGB composition (4d) of the non-processed photograph and the results of Moran index and directional filter angle provide the best method to visualize the extant surface features of the Late Roman villa (Fig. 4).
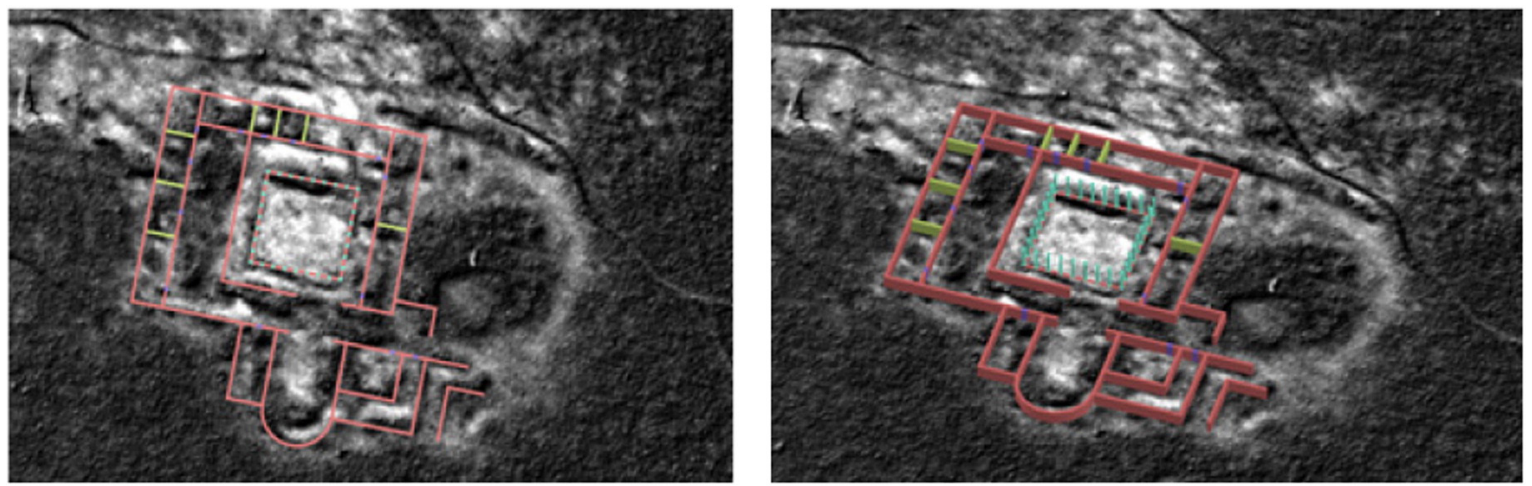

The reduction of noise and the enhancement of the edges allowed a better recognition of the main architectural features of the villa, which seem to focus around a square courtyard, surrounded on its north and west sides by rectangular elements, and on its south and east sides by two semi-circular shapes, interpreted as buildings and exedras. The image processing results are all the more significant since modern buildings dominate the area and have completely erased all traces of the ancient ground plan. The final results enabled the construction of a base map on which all subsequent geophysical mapping and reconstruction of the architectural plan was made.

\section{GPR field instrumentation and data acquisition}

The GPR survey was carried out using a georadar Hi Mod IDS system with 200 and $600 \mathrm{MHz}$ antennae. The following acquisition parameters were employed: 1) 16 bit word length 2) 1024 samples per scan 3) recording time window: $160 \mathrm{~ns}$ for $200 \mathrm{MHz}$ antenna, $80 \mathrm{~ns}$ for $600 \mathrm{MHz}$ antenna. The surveyed grid was $90 \times 70 \mathrm{~m}^{2}$ with reflection profiles

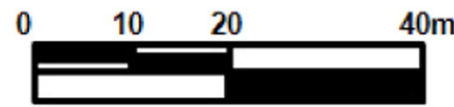

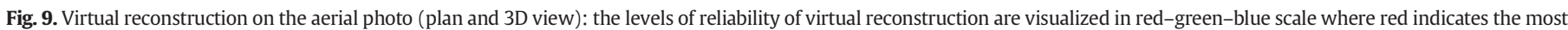
likely, blue the higher level of interpretation. (For interpretation of the references to colour in this figure legend, the reader is referred to the web version of this article.) 


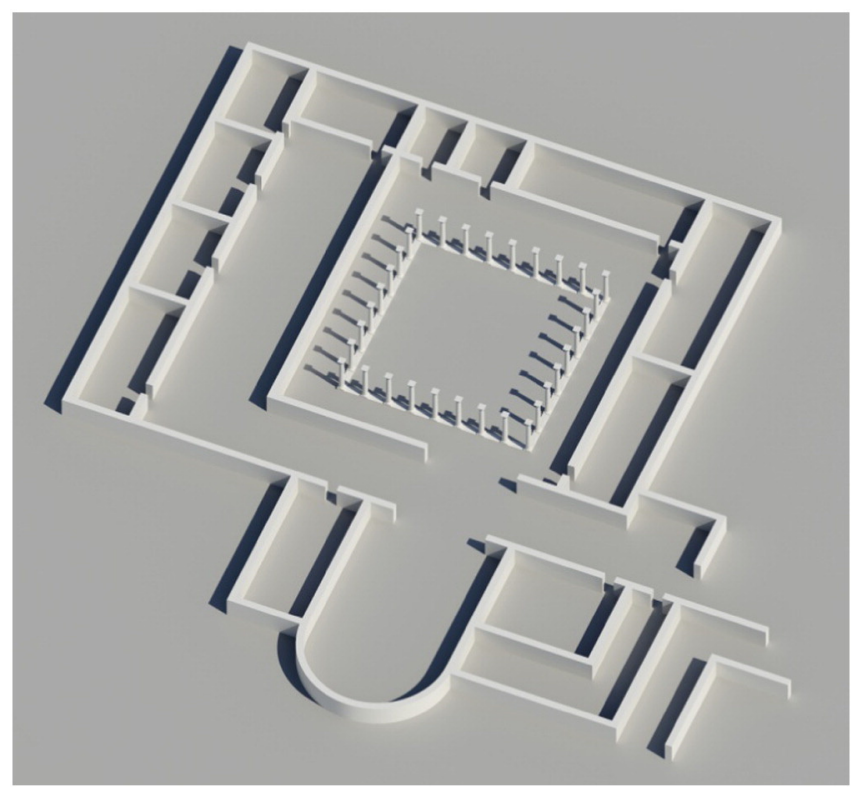

Fig. 10. 3D reconstruction of the Roman villa in grey scale.

spaced $1 \mathrm{~m}$ apart. The choice of the area to investigate with the GPR is based on the analysis of the aerial photographic record described previously. These photos provided an insight into the development of the city.

\subsection{GPR data processing and analysis}

The quality of raw data required appropriate processing for easier interpretation. Processing steps can be summarized as follows:

1) amplitude normalization; consisting of the de-clipping of saturated (and thus clipped) traces by means of a polynomial interpolation procedure (Pipan et al., 1999);

2) background removal filter;

3) Kirchhoff 2D-velocity migration (Scollar et al., 1990); a time migration of a two-dimensional profile on the basis of a 2Dvelocity distribution.

In order to transform the time axis into a depth axis, the electromagnetic (EM) wave velocity was measured from the reflection profiles acquired in continuous mode, using the characteristic hyperbolic shape of reflection from a point source (Conyers, 2012). The application of this method provides an average EM wave propagation velocity of $0.072 \mathrm{~m} / \mathrm{ns}$.

Most of the observed reflection features visible in the profiles (Fig. 5) were recorded from about $0 \mathrm{~ns}$ to about $50 \mathrm{~ns}$. In the time range $2-20 \mathrm{~ns}$ (0.07-0.7 $\mathrm{m}$ depth) the shape and dimensions of the reflected features suggest the presence of a heavily anthropogenic zone characterized by a network of buried pipes $(S)$. In the time range $25-50$ ns (0.9$1.8 \mathrm{~m}$ depth) the shape and alignment of the reflections (labelled A) suggests that they are related to the archaeological structures, most likely walls. Furthermore in all radar profiles a slightly undulating planar reflection horizon (labelled B) is clearly identifiable from about $10 \mathrm{~ns}$ to about $20 \mathrm{~ns}$ ( $0.35 \mathrm{~m}$ to $0.7 \mathrm{~m}$ in depth). This reflection surface is interpreted as a compact layer associated with the 1928 floor surface, prior to filling and levelling for subsequent urban construction. A useful method of GPR data 3D visualization is amplitude slice-mapping, which creates maps of reflected wave amplitude differences in discreet horizontal time slices within a grid (Conyers, 2004, 2006; Goodman et al., 1998, 2004; Leckebusch, 2003; Conyers, 2012, 2013). This type of visualization plays an important role in unravelling the complex layers within urban settings and the evolution of buildings and urban landscapes through time (Conyers, 2012, 2013).

Amplitude slice-maps were constructed in $33 \mathrm{~cm}$ depth slices (after radar travel times were corrected for velocity). The slices from $0.23-$ $0.56 \mathrm{~m}$ and $0.6-0.93 \mathrm{~m}$ depth (Fig. 6) shows underground utilities (S). In progressively deeper slices (Fig. 6), from 1.16 to $2.25 \mathrm{~m}$, the Roman villa structure was visible (V) as was the high amplitude anomaly (R) interpreted as bedrock.

One approach for visualizing 3D iso is the use of surface rendering, assembled from all processed radargrams (Zanzi and Valle, 1999; Goodman and Piro, 2013). In Fig. 7 the same data set is displayed with iso-amplitude surfaces using the threshold value $30 \%$ for the maximum complex trace amplitude. Whilst lowering the threshold value increases the visibility of the main anomaly and smaller objects, it also increases heterogeneity noise.

A relatively strong continuous reflection is visible on the threshold volumes (between 1 and $2 \mathrm{~m}$ ). This visualization technique provides strong evidence for the anomaly related to the Roman villa. In addition, there are also other structures that could be related to archaeological remains. Amplitude slice-maps at depths of between 1.39 and $1.72 \mathrm{~m}$ were overlapped to the city plan and compared with the image from the 1928 aerial photograph (Fig. 8) and it is possible to see an exact correspondence between the result of geophysics and the structures visible on the photo.

\section{3D reconstruction}

For archaeological sites, it is important to get as much information as possible in order to provide an interpretation and in order to plan later excavations. Knowledge of the spatial distribution of buried remains, their shape, depth and, if possible, indications of former usage are highly desirable.

The results presented in this paper describe a multi-methodological approach that surpasses the results that would be achieved if only one method had been used, especially in an urban context. The aerial photographs were used to relocate the Roman villa and guide the location of the GPR survey. The comparison of the results of the two prospection methods clearly illustrates the potential of the combined archaeological interpretation. The GPR prospection results compare well with aerial photographs (Fig. 8). However, GPR delivers much sharper results and many more details including: (1) the depth (1.16-2.25 m) of the structure buried by later urbanization; (2) the parts of the structure destroyed by over 70 years of human activity in the area. However, the further interpretation process is based upon the experience and knowledge of the interpreter, who identifies archaeological structures by mental comparison with recognized anomalies and structures known from the photo.

The integration of the air photos and GPR images clearly show a large square peristyle (i.e. open colonnade in a building surrounding a court that may contain an internal garden) surrounded by a gallery and other structures of the villa (Fig. 8). The dimensions of about $40 \mathrm{~m}$ in length and $30 \mathrm{~m}$ in width, together with the wall thickness of $0.6 \mathrm{~m}$ are typical of a Roman villa (McKay, 1998). The combined interpretation of GPR and aerial photo showed smaller rooms around $5 \mathrm{~m}$ wide with a $5 \mathrm{~m}$ wide porticus facing the open square (Fig. 9).

The archaeological interpretation model derived from the combined prospection data can be visualized three-dimensionally and this allows the specialist as well as the wider public to gain an understanding of the buried archaeological remains (Fig. 9). On the basis of this interpretation model, computer aided reconstruction can be used to further illustrate the results of such work to a wider audience (Apollonio et al., 2013; Bentkowska-Kafel et al., 2012; Forte, 2007; Gabellone, 2009; Gkintzou et al., 2012). By combining archaeological knowledge with architectural construction techniques from the Roman period, a virtual reality model can be reconstructed for the villa (Fig. 10). 


\section{Conclusions}

The case studied presented in this paper shows the feasibility of integrating aerial photographic images with GPR data in an urban area, which can be used as the basis for locating and mapping buried archaeological structures. In this case-study, the aerial photography taken in 1928 revealed the existence and the location of an ancient Late Roman villa, which was excavated in the 1920s.

After analysis of the aerial photographs, a GPR survey was undertaken with the aim of gaining a higher resolution understanding of the site of the Roman villa. The collected data allowed a detailed reconstruction of the villa and archaeological interpretation model. These showed that a large building complex covered an area of about $1200 \mathrm{~m}^{2}$ and was composed of several halls of about $25 \mathrm{~m}^{2}$. One of these halls had an apse. Beside these important layout features, additional information was captured regarding the depth of foundations, fill composition, as well as the height of the remaining walls and the position of wall debris. The depth of penetration depth by modern ploughs was also recorded.

The results of this study and the interpretation methods developed, demonstrate the importance of GPR as a technique in urban archaeological geoprospection. This prospection technique is not only important from the scientific viewpoint, but in providing information that can be used in development-planning, helping to inform archaeological as well as development work within this important historic zone.

\section{References}

Aerial photos taken in 1928 by private company SARA (Società Anonima Rilevamenti Aerofotogrammetrici), preserved in the Archive of Istituto Geografico Militare (IGM), in Florence.

Anselin, L. 1995. Local indicators of spatial association LISA. Geogr. Anal. 27, 93-115.

Apollonio, F.I., Gaiani, M., Sun, Z., 2013. 3D modeling and data enrichment in digital reconstruction of architectural heritage. ISPRS Archives XL-5/W2, pp. 43-48.

Bentkowska-Kafel, A., Baker, D., Denard, H. (Eds.), 2012. Paradata and Transparency in Virtual HeritageDigital Research in the Arts and Humanities Series. Ashgate.

Boemi, M.F., 2003. Le raccolte aerofotografiche. In: Guaitoli, M. (Ed.), Lo sguardo di Icaro. Le collezioni dell'Aerofototeca Nazionale per la conoscenza del territorio, Roma, pp. 29-42.

Ciminale, M., Ricchetti, E., 1999. Non-destructive exploration in the archaeological park of Metaponto (southern Italy). Archaeol. Prospect. 6, 75-84.

Ciminale, M., Gallo, D., Lasaponara, R., Masini, N., 2009. A multiscale approach for reconstructing archaeological landscapes: applications in northern Apulia (Italy). Archaeol. Prospect. 16, 143-153.

Collier, P., 2002. The impact on topographic mapping of developments in land and air survey: 1900-1939. Cartogr. Geogr. Inf. Sci. 29 (3), 155-174.

Conyers, L.B., 2004. Ground-Penetrating Radar for Archaeology. Altamira Press, Walnut Creek, California.

Conyers, L.B., 2006. Innovative ground-penetrating radar methods for archaeological mapping. Archaeol. Prospect. 13 (2), 139-141.

Conyers, L.B., 2012. Interpreting Ground-Penetrating Radar for Archaeology. Left Coast Press, Walnut Creek, CA.

Conyers, 2013. Ground-Penetrating Radar for Archaeology. Third edition. Altamira Press, Walnut Creek, California.

Conyers, L.B., Goodman, D., 1997. Ground-Penetrating Radar: An Introduction for Archaeologists. AltaMira, Walnut Creek, California.

Dokle, P., 2008. Study on geo-engineering conditions of the area of construction of energetic and industrial park of Spitalle-Durres. Albanian Geological Survey, Tirana.

Forte, M., 2007. La villa di Livia: un percorso di ricerca di archeologia virtuale. L'Erma di Bretschneider, Roma.

Gabellone, F., 2009. Ancient contexts and virtual reality: from reconstructive study to the construction of knowledge models. J. Cult. Herit. 10 (Supplement 1), 112-117.
Gkintzou, C., Georgopoulos, A., Valle Melón, J.M., Rodríguez, M.Á., 2012. Virtual reconstruction of the ancient state of a ruined church. EuroMed 2012, Progress in Cultural Heritage Preservation, LNCS 7616. Springer-Verlag, Berlin-Heidelberg, pp. 551-567.

Goodman, D., Piro, S., 2013. GPR remote sensing in archaeology. Geotechnologies and the Environment Series 9. Springer-Verlag, Berlin (233 pp.).

Goodman, D., Nishimura, Y., Hongo, H., Okita, M., 1998. GPR amplitude rendering in archaeology. Proceedings of the Seventh International Conference on Ground Penetrating Radar, May 27-30, 1998Radar Systems and Remote Sensing Laboratory, University of Kansas. University of Kansas, Lawrence Kansas, USA, pp. 91-92.

Goodman, D., Piro, S., Nishimura, Y., Patterson, H., Gaffney, V., 2004. Discovery of a 1st century AD Roman amphitheatre and other structures at the Forum Novum by GPR. J. Environ. Eng. Geophys. 9, 35-42.

Lasaponara, R., Masini, N., 2012. Image enhancement, feature extraction and geospatial analysis in an archaeological perspective. In: Lasaponara, R., Masini, N. (Eds.), Satellite Remote Sensing: A New Tool for Archaeology. Springer, pp. 17-64.

Leckebusch, J., 2003. Ground-penetrating radar: a modern three-dimensional prospection method. Archaeol. Prospect. 10, 213-240.

Leucci, G., 2002. Ground-penetrating radar survey to map the location of buried structures under two churches. Archaeol. Prospect. 9 (4), 217-228.

Leucci, G., 2006. Contribution of ground penetrating radar and electrical resistivity tomography to identify the cavity and fractures under the main church in Botrugno (Lecce, Italy). J. Archaeol. Sci. 33, 1194-1204.

Leucci, G., Negri, S., 2006. Use of ground penetrating radar to map subsurface archaeological features in an urban area. J. Archaeol. Sci. 33, 502-512. http://dx.doi.org/10.1016/ j.jas.2005.09.006.

Leucci, G., De Giorgi, L., Scardozzi, G., 2014. Geophysical prospecting and remote sensing for the study of the San Rossore area in Pisa (Tuscany, Italy). J. Archaeol. Sci. 52, 256-276.

Malagodi, S., Orlando, L., Piro, S., Rosso, F., 1996. Location of archaeological structures using GPR method: three-dimensional data acquisition and radar signal processing. Archaeol. Prospect. 3, 13-23.

McCann, W.A., 1995. GPR and archaeology in central London. Archaeol. Prospect. 2, $155-166$.

McKay, A.G., 1998. Houses, Villas, and Palaces in the Roman World. The Johns Hopkins University Press, Baltimore and London.

Mulvin, L., 2002. Late Roman Villas in the Danube-Balkan Region, BAR IS 1064, Oxford.

Piccarreta, F., Ceraudo, G., 2000. Manuale di aerofotografia archeologica. Metodologia, tecniche e applicazioni, Bari.

Pipan, M., Baradello, L., Forte, E., Prizzon, A., Finetti, I., 1999. 2-D and 3-D processing and interpretation of multi-fold ground penetrating radar data: a case history from an archaeological site. J. Appl. Geophys. 41, 271-292.

Rovigatti, P. (Ed.), 2010. A Square for the City, Images, Studies and Projects for Liria Square in Durrës. Aracne, Roma.

Santoro, S., 2010. Epidamnos, Dyrrachium, Dyrrachion: trasformazioni urbanistiche e culturali di un Porto fra Oriente e Occidente. Bollettino di Archeologia online, I/Volume speciale C/C11/4, pp. 23-36.

Santoro, S., 2012. Ricerche, studi e scavi italo-albanesi a Durrës fra 2001 e 2010. Un primo bilancio. In: De Maria, S. (Ed.), Le ricerche delle missioni archeologiche in Albania nella ricorrenza dei dieci anni di scavi dell'Università di Bologna a Phoinike (20002010). Atti della Giornata di Studi (Università di Bologna, 10 novembre 2010), Bologna, Ante Quem, pp. 91-109.

Santoro, S., Monti, A., 2004. Carta del rischio archeologico della città di Durrës: metodologia di realizzazione e istruzioni per l'uso. In: Santoro, S., Buora, M. (Eds.) Atti del $2^{\circ}$ e $3^{\circ}$ incontro scientifico del Progetto Durrës. Strumenti per la salvaguardia del patrimonio archeologico: carte del rischio e catalogazione informatizzata (Villa Manin di Passariano-Udine-Parma, 28-30 marzo 2003) e Alte tecnologie applicate all'archeologia di Durrës (Durrës, 24 giugno 2004), Trieste, pp. 525-562.

Santoro, S., Sassi, B., 2010. Fra terra, mare, colline e lagune: le aree suburbane di Dyrrachium (Durrës, Albania). In: Vaquerizo, D. (Ed.), Las Áreas Suburbanas en la ciudad histórica. Topografía, usos, función (Córdoba, 2010). Monografías de Arqueología Cordobesa 18, pp. 35-52.

Scollar, I., Tabbagh, A., Hesse, A., Herzog, I., 1990. Archeological Prospecting and Remote Sensing, Cambridge.

Zanzi, L., Valle, S., 1999. Elaborazione di dati GPR 3D per la ricerca di mine antiuomo. Atti del $18^{\circ}$ Convegno Nazionale del Gruppo Nazionale di Geofisica della Terra Solida (Roma, Novembre 1999), Roma.

Zeqo, M., 1986. Dëshmi të artit të lashtë në Durrës. Iliria 1, 179-185. 